\title{
SHRNUTÍ PRIMÁRNÍHO VÝZKUMU VZDĚLÁVACÍHO PROJEKTU Č.: 22410420011 INOVACE - CESTA KE ZVYŠOVÁNÍ KONKURENČNÍ SCHOPNOSTI A ROZVOJE REGIONÜ ${ }^{1}$
}

\author{
Adam Černý, Marie Gabryšová
}

\section{Klíčová slova:}

Lidské zdroje, primární výzkum, podnikové vzdělávání, přeshraniční spolupráce, inovace.

\section{Key words:}

Human resources, primary research, company education, cross-border cooperation, innovation.

\begin{abstract}
Abstrakt
Článek se zabývá metodikou a dílčími výsledky primárního výzkumu projektu přeshraniční spolupráce, který probíhá na Slezské univerzitě, Obchodně podnikatelské fakultě v Karviné. V první kapitole článku je stručně vypsáno zadání projektu, jeho cíle a časový rámec. V druhé kapitole je popsána metodika sekundárního a primárního výzkumu, dále jsou zde shrnuty klíčové ukazatele projektového výzkumu a jejich souvislost s dalšími fázemi projektu. Ve třetí kapitole jsou vyjmenovány faktory, které v průběhu výzkumných aktivit projektu pozitivně nebo negativně ovlivňovaly sběr dat a jsou zde stručně popsány způsoby řešení a jejich konečný dopad.
\end{abstract}

\begin{abstract}
This article deals with primary research methodology and partial results of cross-border cooperation project, which takes place at Silesian University in Opava, School of Business Administration in Karviná. In the first chapter there are a brief project settings, goals and timeframe description. The second chapter describes secondary and primary research methodology, key project research indicators and their links to next project phases. In the third chapter there are listed factors with positive or negative impact on data collection process. A brief description of their solutions and final impact is listed too.
\end{abstract}

\section{Úvod}

V současné době jsme svědky fundamentální transformace podnikání. Prahalad a Krishnan (2010) uvádí: „,V důsledku digitalizace komunikačních sítí a globalizace povede transformace k radikální změně podstaty podniku (organizace) a způsobu tvorby hodnot. “ Žádná oblast podnikání není imunní vůči těmto změnám. Lze vnímat rostoucí vliv inovací na zvyšování efektivity procesů probíhajících $\mathrm{v}$ hospodářství. Ekonomové se shodují v názoru, že vliv inovací na hospodářství je velmi významný. Pomykalski (2001, s. 11-12) uvádí, že působení inovací na společensko-hospodářský rozvoj je spojováno s těmito faktory:

- koncentrace velkých finančních prostředků určených na rozvoj vědy, což umožňuje vytvářet moderní, vysoce efektivní, technicky i kádrově vybavené vědecko-výzkumné instituce,

- silné propojení vědy s výrobou, vnitřním a světovým trhem, což ovlivňuje orientaci vědecko-výzkumné činnosti, která se tak stává více orientovanou na potřeby trhu,

\footnotetext{
${ }^{1}$ Článek je dílčím výstupem projektu č. 22410420011 "Inovace - cesta ke zvyšování konkurenční schopnosti a rozvoje regionů“ financovaného z programu Přeshraniční spolupráce ČR - SR 2007 - 2013.
} 
- inovace jsou vnímány jako proces, který je třeba správně řídit, a to jak na úrovni podniku, regionu, státu či EU.

Chtějí-li organizace rozvíjet svou činnost a udržet si konkurenceschopnost na dynamicky měnicích se trzích, musí se vyznačovat flexibilitou jak ve vztahu ke změnám, tak v přizpůsobování své činnosti právě těmto změnám, probíhajícím v tržním prostředí. Dolinska (2010, s. 9) píše, že „,inovační organizace se snaží vyrovnat se s takovou výzvou a trvale rozvíjí své kompetence v průběhu realizace inovačních procesů, zavádění inovací do své činnosti, a také jejich širokého zavádění na trzích“. Malátek (2011, s. 134) k tomu dodává, že ,je důležité zdůraznit skutečnost, že pokud dochází k rozvoji pracovníků, v konečném důsledku dochází také k rozvoji podniku jako celku“. Dudová a Polonyová (2011, s.49) zároveň tvrdí, že „,dopad společenských a ekonomických vlivů zesiluje příznivé působení politiky vzdělávání a odborné přípravy na trvalou udržitelnost, zaměstnanost a ekonomickou prosperitu v podobě zavádění nových způsobů organizace vzdělávání, inovačních metod“.

Inovační kompetence organizace jsou výsledkem vzdělávání se jeho pracovníků, a také spolupráce $\mathrm{s}$ partnerskými podniky a zákazníky $\mathrm{v}$ průběhu realizace inovačních procesů. Schopnost organizace asimilovat vnější znalosti a dovednosti je závislá také na schopnostech organizace vytvářet inovační relace s účastníky inovačního prostředí, ve kterém se realizují změny zaměřené na vytváření a zavádění inovací.

Vzdělávací projekt č.: 22410420011 Inovace - cesta ke zvyšování konkurenční schopnosti a rozvoje regionů, který je financován v rámci programu přeshraniční spolupráce Slovenská republika - Česká republika 2007 - 2013 reaguje na probíhající změny a klade si za cíl zprostředkovat malým a středním podnikům, podnikatelům a podnikatelkám, studentům, absolventům a nezaměstnaným nové informace a znalosti. Ty jim pomohou v lepším rozpoznávání nových příležitostí, rozvoji inovačního potenciálu ve smyslu neustálého zlepšování všech aktivit a tím v konečném důsledku zvýší jejich konkurenční potenciál.

\section{Předpoklady a náplň realizace projektu}

Výchozí předpoklad pro zahájení tohoto projektu je, že na ekonomických výkonech Moravskoslezského a Žilinského kraje se významnou měrou podílí malé a střední podniky do 250 zaměstnanců a jejich potenciál flexibilní reakce na aktuální trendy je do jisté míry oslaben nižší úrovní kompetencí a znalostí zaměstnanců. Tato je způsobena omezenými finančními prostředky na jejich rozvoj, ztî̌ženým přístupem $\mathrm{k}$ podpůrným finančním prostředkům Evropské unie a neznalostí toho, jak o tyto zdroje požádat a využít je. V projektu usilují obě zúčastněné univerzity (Žilinská univerzita a Slezská univerzita) o maximálně efektivní využití prostředků pro vzdělávání zaměstnanců zúčastněných podniků a studentů v oblastech, které sami určí jako klíčové pro jejich další rozvoj. S pomocí zpětnovazebního vzdělávání, praktických workshopů a poskytování expertních služeb ve spolupráci s univerzitou si klade projekt za cíl zvýšit inovační potenciál a konkurenční schopnost cílových skupin tak, aby nebyli nuceni opouštět trhy v Moravskoslezském kraji a Žilinském samosprávném kraji, účastnit se ekonomických aktivit a snadněji se uplatňovat na místních, celorepublikových nebo mezinárodních trzích. Hlavní oblasti vzdělávání projektu jsou uspořádány $\mathrm{v}$ tzv. modulech. Jejich volba vyplývá z uskutečněného primárního výzkumu, kde respondenti vybírali z jednotlivých možností vzdělávání ty, které nejsou schopni vlastními silami dostatečně zabezpečit. Šest modulů tvoří Počítačové dovednosti, Marketingové řízení podniku, Projektový management, řízení a plánování v projektech z fondů EU, Strategické ř́zení a plánování, Komunikace v cizím jazyce a Inovativní management lidských zdrojů. 


\subsection{Př́ípravná fáze}

$\mathrm{V}$ př́ípravné fázi projektu došlo $\mathrm{k}$ vytvoření projektového týmu a pracovních skupin, základnímu personální zabezpečení projektu, tj. obsazení míst projektového manažera, vedoucích projektových kanceláŕí, administrátora/asistenta, koordinátora školicích aktivit, ekonoma, účetního, personálního pracovníka a vytvoření expertních týmů a pracovních skupin na slovenské a české straně projektu. Během přípravné fáze projektu byla také zprovozněna Česko slovenská kanceláŕ inovací a rozvoje regionů, která slouží k trvalému kontaktu s partnery a účastníky projektových aktivit. Provoz kanceláře, zabezpečení koordinace s partnerskou kanceláŕí na Slovensku, výběr základních oblastí poradenství a vzdělávání pro zainteresované skupiny na základě dosavadních znalostí situace v regionu probíhá průběžně přes celé projektové období. Projektové kanceláře jsou vytvořeny na české i slovenské straně.

\subsection{Výzkumná fáze}

Výzkumná fáze projektu zahrnuje přípravu a realizaci výzkumu aktuální situace mezi podnikateli $\mathrm{v}$ regionu (sekundární výzkum) a př́pravu materiálů pro primární výzkum v terénu a jeho realizaci. Ta je zajištěna tazateli osobním a elektronickým dotazováním pomocí standardizovaného dotazníku mezi subjekty v regionu (český projektový tým zodpovídá za 450 respondentů, z toho minimálně 200 podniků, 150 studentů a doktorandů a 100 libovolně, slovenský projektový tým měl taktéž kvótu 450 respondentů). Dotazování probíhalo od října 2010 do března 2011 ve všech okresech Moravskoslezského kraje. V rámci výzkumné fáze si manažer a koordinátor projektu kladli za cíl oslovit přímo i nepřímo co největší počet potenciálních zájemců o následné vzdělávací aktivity. Proto byly v průběhu třetího a čtvrtého kvartálu roku 2010 osloveny úřady a instituce $\mathrm{v}$ městech Moravskoslezského kraje. Soustředili jsme se na městské a krajské úřady, živnostenské úřady a instituce, které jsou v každodenním kontaktu s malými a středními podniky - Hospodářské komory a Českou marketingovou společnost. Z celkového počtu 37 oslovených úřadů a institucí s námi spolupracovaly pouze $\mathrm{v}$ pěti případech, $\mathrm{u}$ všech ostatních byla naše žádost zamítnuta, nebo nebyla zodpovězena. Spolupráce se nezdařila ani u úřadů a institucí, které jsou pro Slezskou univerzitu a Obchodně podnikatelskou fakultu partnery (Magistrát města Karviná, ŽÚ Karviná, ČMS). Spolupráce při publicitě projektu a jeho výzkumných aktivit probíhala formou zveřejnění odkazů na elektronický dotazník, umístěný na Google Docs, v některých případech byl přímo zveřejněn aktivní banner. $\mathrm{Na}$ možnost zúčastnit se vzdělávání byli upozorněni i podnikatelé zakládající novou živnost na Žú Odry. Reprezentativnost výběrového souboru vyplývá z požadavků na primární výzkum, které byly stanoveny při schvalování projektu. Finální výběrový soubor MSP primárního výzkumu je z pohledu právní formy podniků vzhledem k základnímu souboru zčásti reprezentativní. Je v něm velmi málo akciových společností, komanditních společností a veřejných obchodních společností (což vylučuje shodu s obecnou strukturou podnikatelských subjektů, ale nevylučuje ji v malém a středním podnikání). Vezmeme-li v úvahu absolutní velikost vzorku (celkem bylo vyplněno 690 dotazníků, z toho 474 od malých a středních podniků a podnikatelů), je ve srovnání s celkovou velikostí základního souboru podnikatelských subjektů v Moravskoslezském kraji výběr malý a spolehlivost je velmi omezená. Specifičtější výzkumy, např. výběrové šetření o inovacích v MSP nad 10 zaměstnanců, které provádí ČSÚ, zahrnují přes šest tisíc respondentư ${ }^{2}$. Cílem výzkumu bylo především stanovit rámcové oblasti vzdělávání, které podniky a podnikatelé chtějí řešit v rámci vzdělávacích aktivit projektu. K těmto účelům byl výběr stanoven vhodně z pohledu právní formy, geografického rozdělení i velikosti podniků.

\footnotetext{
${ }^{2}$ viz www.czso.cz/csu/2012edicniplan.nsf/t/E4001C696C/\$File/96051201.pdf
} 


\subsection{Vzdělávací fáze}

Vzdělávací fáze projektu zahrnuje aktivity jako příprava, tvorba a vydání tréninkových materiálů pro vzdělávací aktivity a činnost podnikatelů, vydání tréninkových manuálů, distribuci a předběžnou realizaci vzdělávání cílových skupin $\mathrm{v}$ jednotlivých modulech v druhém a třetím roce projektu. Obsah jednotlivých vzdělávacích modulů byl finálně specifikován na základě výsledků primárního výzkumu, vybráno bylo šest nejžádanějších oblastí vzdělávání, které cílové skupiny nejsou schopny dostatečně pokrýt vlastními silami. Vzdělávání v projektu je zajištěno ve spolupráci s Institutem Euroschola, o. s., který je vítězem výběrového řízení na dodání vzdělávacích služeb projektu.

\section{Metodologie sekundárního a primárního výzkumu}

V rámci druhé fáze projektu, ve které byla realizována výzkumná část, byl na fakultách obou zúčastněných univerzit realizován sekundární a primární výzkum v zohledněných oblastech ve specifických cílových skupinách. Sekundární výzkum, který předcházel primárnímu, byl realizován na půdě Slezské univerzity v druhém a třetím kvartálu roku 2010 a jeho poslední fáze se překrývala s počátkem realizace primárního výzkumu. Tento primární výzkum byl zahájen koncem třetího kvartálu a ukončen ve čtvrtém kvartálu roku 2010. Další aktivity primárního výzkumu pokračovaly $\mathrm{v}$ roce 2011. Výsledky sekundárního a primárního výzkumu slouží jako podklady pro organizaci, zpracování a realizaci následných, zejména vzdělávacích, aktivit $\mathrm{v}$ projektu. Cílem projektu je zvýšení konkurenční schopnosti a výkonnosti společného Česko-Slovenského regionu (Moravskoslezský a Žilinský kraj) prostřednictvím vzdělávání, poradenské činnosti a výměnou zkušeností mezi jednotlivými fakultami, podnikatelskými sdruženími a podnikateli v oblasti podpory a zavádění nových manažerských přístupů do praxe malých a středních podniků. Cílem výzkumné části je provést komplexní zmapování podpory malého a středního podnikání v dotčených krajích, inovačního potenciálu a inovačních aktivit a také určit, o které konkrétní oblasti vzdělávání zaměstnanců mají malé a střední podniky zájem. Východiskem pro stanovení tohoto cíle je nízká konkurenční schopnost malých a středních podniků $\mathrm{v}$ dotčených krajích, zaostalost úrovně výrobních zařízení, moderních metod práce, technologií, BOZPP a připravenost zaměstnanců a OSVČ na práci v turbulentním a vysoce konkurenčním prostředí. ${ }^{3}$ Obdobné závěry, včetně získaných informací o inovačních aktivitách MSP v Moravskoslezském kraji vyplývají z šetření o inovačních aktivitách MSP v ČR, které publikoval ČSÚ. ${ }^{4}$ Konkrétně se jedná např. o mírné snížení inovačních aktivit malých a velkých podniků (střední podniky inovační aktivitu zachovaly), nadpoloviční většinu inovujících MSP a výraznější pokles inovační aktivity v sektorech služeb a zpracovatelském průmyslu. Podniky také více inovují netechnicky, tj. $\mathrm{v}$ rámci marketingových a organizačních inovací a výrazněji tlumí produktové a procesní inovace.

\subsection{Sekundární výzkum}

Cílem sekundárního výzkumu bylo zjistit přesný stav existence dokumentů a informací, které přispěly nebo přispívají ke zmapování aktuální situace podnikatelského prostředí ve zkoumaných regionech. Tyto dokumenty a informace vědecky prozkoumat a zpracovat pro použití v primárním výzkumu. Tyto zpracované výsledky sekundárního výzkumu sloužily jako podklad pro primární výzkum a pro jednotlivé respondenty, tzn., že primární výzkum bezprostředně navazoval na sekundární. V sekundárním výzkumu bylo stanoveno kromě hlavního cíle také několik vedlejších cílů:

- připravit podklady pro primární výzkum a jednotlivé skupiny respondentů,

\footnotetext{
${ }^{3}$ Vnitřní projektové materiály zpracované pro potřebu realizace sekundárního a primárního výzkumu

${ }^{4}$ viz: http://www.czso.cz/csu/tz.nsf/i/inovacni_aktivity_podniku_v_obdobi_2008_2010_20120312
} 
- podrobná analýza a studium dostupných údajů ohledně podnikatelského prostředí,

- podrobná analýza a studium dostupných údajů ohledně regionálního rozvoje,

- komparace výsledků mezi zúčastněnými regiony.

Sekundární výzkum se zabýval těmito oblastmi a otázkami:

- stručný rámcový přehled o geografickém umístění, dopravní, politické, správní a ekonomické struktuře regionů.

- Jaká je hospodářská struktura regionů, jaké odvětví zaměstnávají nejvíce zaměstnanců, které sektory tvoří nejvyšší přidanou hodnotu, jaká je v této struktuře pozice malého a středního podnikání a dalších cílových skupin?

- Jaký je hospodářský potenciál daných regionů, jaké jsou prognózy hospodářského vývoje, jaký je vztah tohoto potenciálu k malému a střednímu podnikání a dalším cílovým skupinám?

- Jaké strategie regionálního rozvoje existují v daných regionech, jak se projevují v praxi, jaký mají vztah k dalším cílovým skupinám?

- Jaké podpůrné mechanizmy a struktury pro malé a střední podnikání a další cílové skupiny existují v daných regionech?

- Jaká jsou nejdůležitější pozitiva a negativa daných regionů ve smyslu regionálního rozvoje a ve smyslu vztahu k dalším cílovým skupinám?

- Aktuální stav možnosti rekvalifikace a vzdělávání malých a středních podnikatelů, resp. pracovní síly - instituce, formy rekvalifikace aj.

- Dosavadní podoba a intenzita přeshraniční spolupráce regionu a hospodářských subjektů v rámci Moravskoslezského regionu.

Pro sekundární výzkum byly stanoveny tyto hypotézy:

- ve zkoumaných regionech existují strategické dokumenty na úrovni samosprávných krajů, které se týkají regionálního rozvoje ve smyslu inovací,

- ve zkoumaných regionech existují podpůrné subvenční mechanizmy, které se týkají finanční a jiné podpory mimo tzv. eurofondy pro malé a střední podnikání,

- ve zkoumaných regionech existují vzdělávání aktivity určené pro malé a střední podnikatele,

- ve zkoumaných regionech existují možnosti podpory malého a středního podnikání $\mathrm{z}$ fondů Evropské unie.

Indikátory sekundárního výzkumu byly jednotlivé dokumenty a informace. Způsob měření významu těchto indikátorů byl rozdělen do tří základních oblastí - základní identifikace, relevantnost a datum, dále územní působnost, vztah dokumentu/informace $\mathrm{k}$ cílovým skupinám výzkumu, návaznost na jiné zdroje a dokumenty a př́íklady použití a v poslední oblasti byl identifikován a kategorizován obsah dokumentu vzhledem ke zkoumaným otázkám. V primárním výzkumu byla ověřována znalost těchto dokumentů a informací v cílových skupinách, a to z pohledu obsahu a pocit’ování jejich účinnosti.

V sekundárním výzkumu bylo mj. zjištěno, že na státní a regionální úrovni je velmi malá informovanost podnikatelských a nepodnikatelských subjektů o možnostech podpory a strategiích rozvoje krajů a měst, celkově je méně srozumitelný postup žádostí o různé formy podpory podnikatelského sektoru a možnosti získání adekvátních lidských zdrojů jsou častou př́čcinou nižší ekonomické aktivity v regionu. 


\subsection{Primární výzkum}

V primárním výzkumu, který navazoval na sekundární výzkum, se zjišt’ovaly a definovaly oblasti, údaje a informace, které nebyly dostupné v sekundárním výzkumu. Hlavním cílem primárního výzkumu bylo zjistit poptávku po podpůrných vzdělávacích aktivitách v malých a středních podnicích $\mathrm{v}$ obou dotčených regionech. Motivem pro takto stanovený cíl je předpoklad následného lepšího uplatnění na trhu práce. Vedlejší cíle primárního výzkumu byly stanoveny takto:

- zjištění stavu obeznámení respondenti̊ s aktuálními možnostmi podpory jejich činností (na regionální i evropské úrovni),

- zjištění spokojenosti nebo nespokojenosti respondentů s podnikatelským a tržním prostředím $\mathrm{v}$ regionu,

- zjištění stavu podílu žen na zkoumané jevy (inovační aktivity, podnikání apod.),

- zjištění spokojenosti nebo nespokojenosti studenti̊ zúčastněných vysokých škol s jejich možnostmi uplatnění se na regionálním trhu práce.

Stejně jako pro sekundární výzkum byly i v primárním výzkumu stanoveny pracovní hypotézy. Malí a střední podnikatelé ve zkoumaných regionech:

- mají relativně malé znalosti o strategických dokumentech, které se týkají možností podpory jejich aktivit (na regionální i evropské úrovni), přibližná úroveň 1/3,

- považují za pozitivní zejména dodavatelsko-odběratelské vztahy, dostupnost a cenu pracovní síly, přibližná úroveň $2 / 3$,

- považují za negativní zejména právní ochranu a vymahatelnost práva, nedostatek požadované kvalifikované pracovní síly a možnosti podnikání. Přibližná úroveň $2 / 3$,

- mají relativně vysoký zájem o vzdělávání v oblasti IT, managementu, marketingu, komunikačních schopností, soft skills apod. Přibližná úroveň $2 / 3$,

- pozice žen $\mathrm{v}$ řídicích a vlastnických strukturách malého a středního podnikání je relativně malá, přibližná úroveň $1 / 3$,

- studenti vysokých škol pocit'ují nedostatky v jejich vzdělání zejména v rámci aktuální praktické orientace, přibližná úroveň $2 / 3$,

- studenti vysokých škol mají tendence samostatně podnikat v průběhu studia a bezprostředně po jeho ukončení, přibližná úroveň $1 / 2$.

Primární výzkum byl realizován týmem tazatelů, jako nejvhodnější metoda získávání dat bylo vybráno dotazování, technikou standardizovaného dotazníku, formou osobního a elektronického dotazování. Tento výběr odpovídal požadovanému rozsahu pokrytí výběrového souboru. Ve všech případech pracovali tazatelé se standardizovaným dotazníkem pro podniky a pro studenty. V elektronické podobě tazatelé využívali jednak elektronické pošty a zasílání dotazníku $\mathrm{v}$ př́loze ve formátu Word, jednak plně automatizované elektronické podoby dotazníku na službě Google Docs, který byl vytvořen jako formulár̆.

Indikátory primárního výzkumu byly jednotlivé oblasti dotazníku (celkem devět v podnikové verzi, pět ve studentské verzi). Podle těchto indikátorů je vyhodnocen primární výzkum v obou regionech. Indikátory u podnikatelských subjektů jsou jmenovitě inovační aktivity, spolupráce mezi podniky, používání nových znalostí, cizích jazyků, vzdělávání zaměstnanců, zaměstnávání žen na manažerských pozicích, informovanost o možnostech podpory ze strany státu, kraje, EU aj. U studentů jsou indikátory hodnocení vzdělání poskytnutého univerzitou, kvalita jazykové př́ípravy, míra podnikatelské aktivity během studia a plánované podnikání po ukončení studia, samovzdělávání studentů voblasti cizích jazyků atd. Na výsledcích 
z primárního výzkumu jsou následně postaveny předběžné závěry a doporučení pro následné projektové aktivity, zejm. pro vzdělávací fázi. Všechny formy dotazování mají stejnou kvalitativní úroveň, $\mathrm{k}$ formě získání dotazníků se však bude přihlížet při vyslovování dílčích závěrů, stejně tak bude zpracováno několik samostatných přehledů:

- porovnat výsledky podle okresů, právních forem a tržní působnosti a podle kombinovaných faktorů,

- porovnat obsazenost manažerských pozic v MSP Moravskoslezského kraje ženami,

- preferovaná forma zabezpečení vzdělávání zaměstnanců, míra spokojenosti s danou úrovní vzdělávání a znalostí zaměstnanců,

- jazykové dovednosti zaměstnanců z pohledu konkrétního jazyka, frekvence a celkové úrovně znalosti,

- seřadit preference ve vzdělávacích aktivitách, vyslovit kvantitativní předpoklady $\mathrm{v}$ jednotlivých aktivitách a zabezpečit je pro realizační fázi,

- vyhodnotit míru informovanosti o strategických aktivitách a dokumentech v Moravskoslezském kraji, zájem o spolupráci s úřady a institucemi, informovanost o možnostech regionální, státní a evropské podpory podnikání,

- přípravné a realizační aktivity $\mathrm{v}$ oblasti inovací $\mathrm{v}$ jednotlivých malých a středních podnicích, jejich účinnost a frekvence,

- rozdíly mezi mírou spolupráce u jednotlivých forem dotazování (formulář Google Docs, email, telefonické dotazování, osobní dotazování),

- rozdíly zájmu o vzdělávání podniků, využívajících externích vzdělávacích služeb o vzdělávání $\mathrm{v}$ projektu $\mathrm{v}$ porovnání $\mathrm{s}$ těmi podniky, které externích služeb nevyužívají,

- porovnat podniky bez potřeby cizího jazyka vzhledem k velikosti, působnosti, formě podnikání a sídlu.

\subsection{Průběh primárního výzkumu}

Primární dotazování bylo zahájeno koncem třetího kvartálu 2010 pilotním dotazováním, ve kterém se dotazník testoval $\mathrm{z}$ pohledu časové náročnosti a dalšího vysvětlování $\mathrm{k}$ jeho vyplnění. Na základě těchto připomínek tazatelů byly dotazníky upraveny a 27. záŕí 2010 bylo spuštěno na české straně ostré dotazování. Na slovenské straně bylo spuštěno o několik dní později. Elektronické dotazování bylo ukončeno na konci listopadu, osobní dotazování bylo ukončeno v únoru 2011.

\section{Terénní dotazování}

Po ukončení terénního dotazování bylo k dispozici celkem 690 jednotlivých dotazníků. Z toho 474 bylo získáno od podniků a 216 od studentů. Počet celkem oslovených podniků odhadujeme na cca 5400 (v osobním dotazování nejsou zcela přesné údaje, u elektronického došlo $\mathrm{k}$ jednotlivým případům vícenásobného oslovení na různých emailových adresách). Počet oslovených studentů je odhadem 600 jednotlivců ve všech formách studia. Za povšimnutí stojí přehled hrubé a čisté návratnosti dotazníků pro jednotlivé skupiny:

Tab. 1 Počet respondentů a návratnost dotazníků

\begin{tabular}{|c|c|c|c|c|c|}
\hline $\begin{array}{c}\text { Typ } \\
\text { dotazníku }\end{array}$ & $\begin{array}{c}\text { osloveno } \\
\text { respondentů }\end{array}$ & odevzdáno & po validaci & $\begin{array}{c}\text { hrubá } \\
\text { návratnost }\end{array}$ & $\begin{array}{c}\text { čistá } \\
\text { návratnost }\end{array}$ \\
\hline podnikový & 5389 & 474 & 372 & $8,8 \%$ & $6,9 \%$ \\
\hline studentský & 578 & 216 & 152 & $37,4 \%$ & $26,3 \%$ \\
\hline
\end{tabular}

Zdroj: vlastní zpracování 
Hrubá i čistá návratnost podnikových dotazníků je oproti původnímu předpokladu na vyšší úrovni (očekávaná návratnost byla 4-5 \%), což lze připsat velkému podílu osobního dotazování, kde si tazatelé $\mathrm{v}$ jednotlivých regionech vedli dobře díky dřívějším kontaktům s dotazovanými subjekty a díky zprostředkování kontaktu na malé a střední podniky prostřednictvím telefonické domluvy konkrétního data a obsahu schůzky. Vysoká hrubá a čistá návratnost studentských dotazníků je způsobena úzkým kontaktem s cílovou skupinou.

\section{Validace}

Ověřování správnosti a úplnosti dotazníků obou druhů, tj. podnikové i studentské verze ve všech formách, bylo nutné provést před převedením dotazníků do seznamů v programu Excel. Tyto elektronické seznamy byly po dokončení zaslány hlavnímu partnerovi na Slovensko, kde byly dále zpracovány do finálních výstupů. Validace probíhala postupně v průběhu prvního kvartálu roku 2011, kdy byl definitivně ukončen sběr dotazníků. Pro validaci podnikových dotazníků byla vytvořena vzorová šablona, ve které byl kladen důraz na kompletnost a konzistentnost jednotlivých indikátorů. Ty dotazníky, které nebyly sto vykázat ani po doplnění u respondentů potřebnou míru úplnosti byly při validaci vyřazeny. Studentské dotazníky prošly stejným způsobem validací bez doplnění chybějících údajů a to z důvodu anonymního vyplnění. Z celkového počtu 690 dotazníků, odevzdaných všemi tazateli bylo $\mathrm{k}$ validaci předáno 663 dotazníků. Zbývající byly vyřazeny pro velké množství chybějících údajů, nečitelnost zápisu, zjevně nepravdivé údaje, duplicitu, prŕípadně pro nevyhovující cílovou skupinu respondenta (více než 250 zaměstnanců, sídlo a aktivní činnost mimo území Moravskoslezského kraje). Souhrn dotazníků po ukončení dotazování, před validací a po jejím ukončení je $\mathrm{v}$ následující tabulce. Vysoká chybovost podnikových dotazníků byla způsobena zejména neochotou podniků a OSVČ vyplnit celý dotazník, neporozumění zadání otázky a také neochota podniků spolupracovat při opravách dotazníků. Z celkového počtu elektronických žádostí o opravu a doplnění údajů se vrátily pouze dvě, což vedlo k vyloučení všech ostatních dotazníků, které nesplňovaly kvalitativní kritéria validace. Ze 140 dotazníků, které byly vyplněny osobně, se podařilo opravit 133 dotazníků, zbývajících sedm bylo taktéž vyloučeno pro nesplnění kvalitativních kritérií validace.

Tab. 2 Průběh validace

\begin{tabular}{|l|c|c|c|c|c|}
\hline $\begin{array}{c}\text { Typ } \\
\text { dotazníku }\end{array}$ & $\begin{array}{c}\text { po ukončení } \\
\text { dotazování }\end{array}$ & $\begin{array}{c}\text { předáno } \mathrm{k} \\
\text { validaci }\end{array}$ & $\begin{array}{c}\text { po ukončení } \\
\text { validace }\end{array}$ & $\begin{array}{c}\text { celkem } \\
\text { vyřazeno }\end{array}$ & $\begin{array}{c}\text { vyřazeno }(\mathrm{v} \\
\%)\end{array}$ \\
\hline podnikové & 474 & 449 & 372 & 102 & $21,5 \%$ \\
\hline studentské & 216 & 216 & 152 & 64 & $29,6 \%$ \\
\hline celkem & 690 & 665 & 524 & 166 & $24,1 \%$ \\
\hline
\end{tabular}

Zdroj: vlastní zpracování

Jak lze vyčíst z výše uvedeného komparativního přehledu dotazníků po ukončení sběru dotazníků a po předání k vyhodnocení na Slovensko, čistá chybovost byla relativně vysoká. Tato chybovost je způsobena zejména tím, že studentské dotazníky nebylo možné vrátit k doplnění (anonymita respondentů) a také tím, že podnikové dotazníky nebyly jednotlivé podniky ochotny znovu vyplnit (v elektronické verzi). Naopak návratnost oprav u osobního dotazování byla velmi vysoká, dosáhla úrovně $95 \%$. Na slovenské straně byla situace velmi podobná, tazatelé se taktéž potýkali s vysokou chybovostí i neochotou $\mathrm{k}$ opravám a doplněním údajů v podnikových dotaznících. Celkový počet 524 dotazníků, které prošly celou validací, převýšil minimální kvótu, požadovanou projektem, o 16,4\%, z toho u podnikových o $86 \%$, u studentských o $1,3 \%$. Projekt počítal s minimálním počtem 450 dotazníků, z toho minimálně 200 podnikových a 150 studentských, 100 dotazníků libovolně. 


\subsection{Přehled závěrů a doporučení primárního výzkumu}

$\mathrm{V}$ průběhu terénního výzkumu a následného vyhodnocení dotazníků bylo zjištěno několik faktorů, které přispívaly různou měrou a intenzitou $\mathrm{k}$ pozitivnímu nebo negativnímu vývoji dotazování. Na některé tyto faktory jsme byli schopni včas reagovat a řídit jejich působení, na některé jsme však neměli dostatečné znalosti a prostředky, jak je včas rozpoznat a ovlivnit v náš prospěch. Jako negativní faktory byly identifikovány zejména:

- neochota spolupracovat na straně podniků (časté zrušení schůzek, domluvených termínů zaslání vyplněného dotazníku, slabá motivace pro vyplnění),

- s publicitou a spoluprací nám až na výjimky nepomáhaly oslovené úrady a instituce,

- žádosti o opravy a doplnění dotazníku u respondentů se zcela míjely účinkem,

- terénní výzkum probíhal pomalu, zejména ve vzdálených lokalitách,

- ve srovnání s podnikatelskou sférou byla odezva tazatelů pomalejší (odpověd' do třetího dne), což podniky znejistilo a do jisté míry odrazovalo od spolupráce,

- kontaktní email byl pro první linii zaměstnanců dlouhý a odtažitý,

- dotazníky ve formátu Word většina podnikatelů nedokázala rychle vyplnit (zjištěno až koncem října), důvodem pravděpodobně nezvyklý formát (ActiveX) a nižšś ICT znalosti,

- geograficky vzdálené podniky předem odmítaly vyplnění, protože považují Karvinou jako místo pro vzdělávací aktivity projektu za př́liš vzdálenou.

Jako pozitivní faktory byly identifikovány:

- oslovení osobních kontaktů tazatelů (lidé z oslovených podniků, podnikatelé, kteří mají kontakty na sféru malého a středního podnikání, osobní doporučení, známé podniky v okolí),

- zjednodušení emailového kontaktu, odstranění přílohy (prevence před spamovými filtry, původní email budil dojem komerční nabídky),

- využití nekomerčních elektronických databází podniků ve vzdálenějších regionech (získáno cca 4900 kontaktů, tj. 92 \% všech oslovení, 43 \% celkových podnikových dotazníků),

- osobní přístup tazatelů v terénním dotazování, jednoduchá motivace.

Pro analogická terénní šetření v obdobných podmínkách, za využití stejných technik a způsobů dotazování jednoznačně doporučujeme zjednodušení kontaktních informací, důsledné informování cílových subjektů o pozitivních dopadech na jejich činnost, jednoduchou motivaci při osobním dotazování a snahu o maximálně osobní př́stup. Při důrazu na kvantitativní ukazatele, které zvyšují vypovídací schopnost celkového zkoumaného souboru ve výzkumu, můžeme doporučit rozesílání stručného informativního emailu na adresy podniků, které lze získat oficiální cestou z bezplatných databází podnikatelských subjektů. Je třeba vzít $\mathrm{v}$ úvahu, že je nutné zabránit duplicitám, proto jsme aplikovali automatické funkce tabulkového procesoru Excel na odstranění duplicitních adres před jejich oslovením. Tímto způsobem se však nelze vyhnout oslovení na emailech, které jsou si sice velmi podobné a tím také duplicitní, nejsou však shodné (nap̌r. seznaminfo@abc.com a seznam.info@abc.com). Takto se při hromadném oslovování firem zdvojilo přibližně 400 kontaktů, z nichž přes 80 \% bylo včas rozpoznáno a odstraněno. Duplicitní oslovení se však míjela účinkem a $\mathrm{k}$ dvojímu vyplnění došlo pouze ve dvou př́ípadech. Celkově hromadné oslovování emailem hodnotíme jako účinné, je však bezpodmínečně nutné dbát na zásady takového oslovení, používat kontrolu duplicit a případné žádosti o vyřazení z kontaktní 
databáze akceptovat (zaregistrovali jsme 4 žádosti). Zároveň je třeba počítat $\mathrm{s}$ tím, že odhadem $10 \%$ všech rozeslaných emailů se nedostane na adresu určení. Důvodem je neaktuální adresa, překlepy a filtrování spamu, případně chyba poštovního serveru.

\subsection{Shrnutí}

V průběhu výzkumu došlo $\mathrm{k}$ několika úpravám ve způsobu a formě oslovení a ke zvýšení intenzity oslovení cílových skupin. Tento krok, jak se později ukázalo, měl klíčový dopad na překročení minimální hranice celkového počtu dotazníků, potřebného k uzavření dotazování se splněnými limity. Na zvýšenou návratnost mělo vliv také převedení podnikového dotazníku do elektronické podoby. Tento byl pro podniky snáze pochopitelný a jeho vyplnění bylo jednodušší, než vyplňování formuláře s prvky ActiveX v dokumentu Word. Taktéž se domníváme, že posílání prŕílohy $\mathrm{v}$ kontaktním emailu vedlo u některých respondentů k blokování obsahu mailu, který byl takto vyhodnocen jako spam, př́padně email s nebezpečným obsahem (prvky maker).

Při ověřování úplnosti dotazníků, které prováděl koordinátor výzkumu, bylo ve většině př́ípadů zjištěno, že docházelo k neúplnému vyplnění dotazníku a v několika případech cílová skupina podniku nesouhlasila s aktuální charakteristikou dotazovaného podniku. Celkem bylo takto vyřazeno 27 dotazníků, ostatní byly předány k validaci mezi všechny tazatele.

Při validaci se podle předem vytvořených šablon každý dotazník zkontroloval, zdali jeho vyplnění odpovídá logické struktuře, tj. zdali na sebe otázky navazují, a tam, kde je nutné dodržet podmíněné otázky, jsou tyto opravdu vyplněny. Validaci prováděli všichni tazatelé podle toho, jak jim byly přiděleny skupiny dotazníků. Dotazníky, které neprošly validací, byly podrobně označeny se seznamem nedostatků a byly předány zpět $\mathrm{k}$ doplnění respondentům. U studentských dotazníků, které nebylo možné takto doplnit, byly chyby zřetelně označeny a nevyhovující dotazníky byly vyjmuty z celkového souboru pro kvalitativní a kvantitativní analýzu výsledků, za kterou zodpovídá hlavní partner na Žilinské univerzitě. Po validaci bylo ze souboru pro analýzu vyřazeno celkem 166 dotazníků. Dohromady s neúplnými dotazníky, nebo dotazníky z jiných než cílových skupin se vyřadilo celkem 193 dotazníků. Důvody vysoké chybovosti a důvody, které vedly ke sníženému počtu oprav elektronických dotazníků, jsou popsány v textu výše.

Díky průběžnému mapování aktivit, zasílání dat pro reporting a sdílení zkušeností a doporučení pro lepší průběh oslovování, vyplňování dotazníků a získávání kontaktů mezi jednotlivými tazateli se podařilo úspěšně uzavřít fázi dotazování částečně již počátkem prosince, kdy jsme překročili počet minimálně požadovaných dotazníků. $\mathrm{K}$ definitivnímu uzavření došlo v únoru 2011. Koordinace aktivit v projektu, která probíhá paralelně u obou partnerských univerzit, vedla k synchronizovanému spuštění a ukončení dotazování, čímž se nám podařilo získat časově harmonizovaná data a zvýšit tak komparativní vypovídací schopnost získaných údajů.

\section{Závěr}

V projektu Inovace - cesta ke zvyšování konkurenční schopnosti a rozvoje regionů v současné době probíhá finální část vzdělávací fáze. V rámci přípravné fáze byla otevřena kancelář pro styk s partnery, jejíž provoz bude pokračovat i po ukončení projektu v rámci Slezské univerzity v Opavě, Obchodně podnikatelské fakulty v Karviné. Ve výzkumné fázi byl ukončen sekundární i primární výzkum. Primární výzkum byl na české straně spuštěn na konci záríi 2010. V elektronické podobě byl primární výzkum ukončen dříve než v terénu, ještě koncem roku 2010, osobní dotazování dále pokračovalo a ukončeno bylo v březnu 2011. 
Projektem požadovaný počet 450 respondentů byl po ukončení dotazování s velkou rezervou překročen. Po validaci zůstalo 524 dotazníků k vyhodnocení. V průběhu terénního výzkumu a následného vyhodnocení dotazníků bylo zjištěno několik faktorů, které přispívaly různou měrou a intenzitou $\mathrm{k}$ pozitivnímu nebo negativnímu vývoji dotazování. Tyto pozitivní nebo negativní faktory jsme popsali a přijali jsme patřičná opatření ještě v průběhu dotazování. Vzdělávací fáze je naplněním hlavního cíle projektu, kterým je trvalé přispění ke zlepšení situace cílových skupin na místních trzích. Sekundární a primární výzkum sloužily k přípravě této fáze a $\mathrm{k}$ deskriptivním účelům, které budou dále sloužit ke zlepšování situace výše popsaných cílových subjektů. Měřitelným cílem projektu je poskytnout různou formou v šesti modulech vzdělání 1680 osobám na české straně projektu.

Veškerá data, která byla získána ze sekundárního a primárního výzkumu projektu jsou $\mathrm{k}$ dispozici pro další výzkumy, je však nutné vzít v potaz citlivou povahu některých údajů, které bylo třeba pro projekt získat, např. kontaktní informace, současné inovační aktivity, rozvojové plány podniků a podnikatelských subjektů, aj. Tato data budou trvale anonymizována, abychom vyloučili jakékoliv zneužití třetím subjektem. Projektové aktivity a výstupy průběžně monitorujeme a publikujeme dílčí výsledky projektových aktivit z primárního výzkumu i ze samotného vzdělávání.

\title{
Literatura:
}

[1] DOLIŃSKA, M. Innowacje $w$ gospodarce opartej na wiedzy. Warszawa: Polskie Wydawnictwo Ekonomiczne, 2010, 156 s. ISBN 978-83-208-1877-2.

[2] DUDOVÁ, I., POLONYOVÁ, S. Aktuálne otázky efektívnosti, rovnosti a kvality vo vzdelávacom prostredí. Karviná 2011. Acta academica karvinensia 1/2011, s. 49 - 57. ISSN 1212-415X.

[3] MALÁTEK, V. Sociálně-psychologické aspekty motivace a rozvoje pracovníků. Karviná 2011. Acta academica karvinensia 4/2011, s. 124 - 135. ISSN 1212-415X.

[4] POMYKALSKI, A. Zarzadzanie innowacjami. Warszawa-Łódz: Wydawnictwo naukowe PWN, 2001, 328 s. ISBN 978-83-011-3480-8.

[5] PRAHALAD, C. K., KRISHNAN, M. S. Nowa era innowacji. Warszawa: Wydawnictwo profesjonalne PWN, 2010, 211 s. ISBN 978-83-01-16192-7.

[6] Vnitřní projektové materiály zpracované pro potřebu realizace sekundárního a primárního výzkumu

[7] ČSÚ [online] Inovační aktivity podniků v období 2008 - 2010 - metodika. [cit. 14-082012] <www.czso.cz/csu/2012edicniplan.nsf/t/E4001C696C/\$File/96051201.pdf>

[8] ČSÚ [online] Inovační aktivity podniků vobdobí 2008 - 2010. [cit. 14-08-2012] $<$ http://www.czso.cz/csu/tz.nsf/i/inovacni_aktivity_podniku_v_obdobi_2008_2010_2012 0312>

\section{JEL J24, M53}

\author{
Ing. Adam Černý, Dr. Ing. Marie Gabryšová \\ Katedra marketingu \\ Slezská univerzita v Opavě \\ Obchodně podnikatelská fakulta v Karviné \\ Univerzitní nám.1934/3, 73340 Karviná \\ cerny@opf.slu.cz, gabrys_m@opf.slu.cz
}

